\title{
TEACHING ENGLISH GRAMMAR WITH CLT AND EXPLANATION METHOD
}

\section{Subaidi dan Haryanto}

UNISNU Jepara

Email: zubaidimasyhud@yahoo.co.id dan hary74pangestu@yahoo.co.id

Teaching English grammar can be taught by some methods. Two of them are communicative language teaching (CLT) and explanation method. Both CLT and explanation method can be used to present the English language materials such as authentic materials, Scrambled sentences, language games, picture strip stories, poems, songs, poetry, map, and role play. Each of them has strength and weakness. Teaching with CLT can make the class become interesting and the student will not get bored. Whereas, by only using the explanation the student will get bored and the teacher as well. In Indonesia CLT is a modified version to adopt teaching English skills such as reading, writing and and speaking. Structural approach is still applied for teaching language elements such as structure/grammar and vocabulary. Explanation method is used to develop reading skill. However, based on the data of test result by the students, the result of explanation technique is more effectively targeted better than CLT.

Keywords: grammar, communicative, explanation, technique, teaching 


\section{A. Introduction}

Teaching grammar has always been a central aspect of foreign language teaching. In some countries Grammar Translation Method was widely used in teaching grammar. It was believed that grammar competence constitutes the backbone of language acquisition. Fauziati states that the concept of Communicative Language Teaching (CLT) firstly emerged and mushroomed in 1970's. It can be said that communicative language teaching (CLT) is the respond of dissatisfaction towards the traditional methods. ${ }^{1}$ Richards and Rodger states that the notion of CLT was firstly presented by Wilkins in 1972 who proposed a functional or communicative definition of language that could serve as a basis for developing communicative syllabuses for language teaching. Wilkins's contribution was an analysis of the communicative meanings that a language learner needs to understand and express. Wilkins later revised and expanded his 1972 document into a book called Notional Syllabuses (Wilkins 1976), which had a significant impact on the development of Communicative Language Teaching. ${ }^{2}$ According to Howatt, CLT to use has two versions: weak and strong. The weak version can be described as learning to use English as the target language and the strong one refers to using English as target language to learn it. The strong version proposed that communicative ability should be emphasized at the beginning of comprehension and production stage since the grammatical ability will be acquired as the learner us the language. ${ }^{3}$ However, it contributes the neglect of grammar teaching in language learning process.

In CTL context, language learning was identified as learning how to use language for communication. Early in the teaching-learning process, the students are encouraged to use second language and the key was 'understood'. In actual practice, however, the neglect of grammar teaching has made the students 'fluent speakers' of the language but produced utterances such as "She my friend, I am live here, Are you agree with me? or I am interesting with the subject".

Recently the teaching grammar started gaining judicious attention on the part of language teachers. The reality is that advocates no grammar teaching was misleading. So, no one can tell you that grammar is irrelevant, or no longer needed in a CTL framework. No one doubts the prominence of grammar as an organizational framework within communication. On the other hand, it can be said that grammar teaching should be neglected. Although in recent trend in language teaching, the focus of teaching should be placed on communicative function rather than grammar, it is still considered as an important aspect of language teaching. Teaching grammar itself can be done by using communicative techniques (meaning-based) or explanation (formbased). Reviewing the underpinning strength and weakness of CLT, this paper will describe and elaborate the teaching English grammar with CLT and explanation method. Some techniques and sample of materials are given to clarify the description.

1 Fauziati, Endang, 2009, Introduction to Methods and Approaches in Second or Foreign Language Teaching, Surakarta: Pustaka Utama, pg 133

2 Richards and Rodger.,1986, Approaches and Methods in Language Teaching, Cambridge: Cambridge University Press, pg. 65

3 Howatt, A.R.R, 1985, A History of English Language Teaching, New York: Oxford U.P, pg 279 


\section{B. Discussion}

\section{Teaching Grammar Using Communicative CLT}

Teaching grammar has often been regarded as a structure base, formal activity. But after the integration of several sources and techniques, which are mainly on communicative activities, the teaching grammar, technique- resource combination are often modified to structure-discourse match and if well developed, they can be used effectively for all phrases of a grammar lesson. In order to make a grammar lesson effective, beneficial, and interesting, a teacher should use some well-developed and fascinating techniques in the classroom. The communicative teaching of grammar can be conducted by using the following techniques:

\section{a. Games}

The latest concern of foreign language teachers is to make the students use the language communicatively. After the realization of communicative competence, activities and techniques that are task-oriented and lead the students to use the language creatively have gained importance. Games, which are task based and have a purpose beyond the production of correct speech, are examples of most preferable communicative activities in the teaching of grammar. Such activities highlight not only the competence but also the performance of learner. Yet they are indispensable parts of a grammar lesson, since they reinforce a form-discourse match. In such activities the attention is on the discourse context.

Games are accordingly organized by rules and enjoyable. Most games require choral responses or group works. Games are generally used after the presentation, in the practice parts, because such communicative tasks can only be handled after mastering sufficient grammar and lexical points. Through well-planned games, learners can practice and internalize vocabulary and grammar extensively as well. Play and competition that are provided by games enhance the students' motivation. They also reduce the stress in the classroom. While playing games, the leaners' attention is on the content of message, not on the language. In process, students acquire language unconsciously since their whole attention is engaged by activity. ${ }^{4}$ The most common game is "Guessing Game" or Richard calls it "Playing twenty questions". In this game, the activity is about Yes/No Questions. ${ }^{5}$ The teaching procedure is conducted by using game with several steps:

1) The students are supposed to work in pairs.

2) One student is asked to be a mysterious guess, and others are to guess who, by using yes/no questions.

That kind of games can be seen below:

4 Saricoban, Arif \& Essen Metin, Songs, Verse, and Games for Teaching Grammar, The Internet TESL, Journal, Vol. VI No. 10, October 2000.

5 Richars, Jack, C. et al, 1990, Interchange 1: English for International Communication, Cambridge: Cambridge University Press. 
A: Do you live in Indonesia?

B: Yes

A: Are you a singer?

$B:$ No

A: Are you a politician?

$B$ : Yes, you are right

A: Do you belong to certain party?

B: Yes. .....etc.

This game must be continued until the mysterious person can be guessed.

b. Using Songs

Since meaning is an important device in teaching grammar, it is important to contextualize any grammar point. Songs are one of the most enchanting and cultural rich sources that can be used in teaching grammar. Songs offer a change routine from activities. They can be used to teach a variety of language items such as sentence pattern, vocabulary, adjective, adverbs, etc. If they are selected and adopted carefully, songs can be taught using the following techniques:

1) Gap fills or close text

2) Focus questions

3) True false statement

4) Multiple choice

A teacher's selection on a technique or a set of techniques should be based on his/her objectives for the classroom. After deciding the grammar point to be studied, the song and the technique to be used, the teacher should prepare an effective lesson plan. ${ }^{6}$ The one of song sample that can be used to teach grammar is "Yesterday" by Beatles. This song can be used to teach tenses especially "past tense"

Here is the transcript of song:

Yesterday

All my troubles seemed so far away

Now it looks as though they're here stay

Oh, I believe in yesterday

Suddenly

I'm not half the man I used to be

There's a shadow hanging over me

Oh yesterday came suddenly

Why she had to go I don't know

She would say

I said something wrong

Now I long for yesterday

Yesterday

Love was such an easy game to play

6 Saricoban, Arif \& Essen Metin, Songs, Verse, and Games for Teaching Grammar, The Internet TESL, Journal, Vol. VI No. 10, October 2000. 
Now I need a place to hide away

Oh I believe in yesterday

Why she had to go .....

Yesterday

Love was such an easy game to play

Now I need a place to hide away

Oh, I believe in yesterday

Mm $\mathrm{mm} \mathrm{mm} \mathrm{mm} \mathrm{mm} \mathrm{mm} \mathrm{mm}$

As a sequence, the use of songs in language classroom provides advantages. They entertain and relax the learners while they are learning or practicing a structure, and they often eliminate the students' negative attitude towards learning. Through providing authenticity and context, they make the grammar point more understandable.

c. Poems

Poems contextualize a grammar lesson effectively like the songs. However, poetry is spoken, repeated, deal with, and considered, it acts as an effective tools to practice a specific grammatical structure. Through repeating and considering the poem, the grammatical structures become deeply internalized. Thus poem not only provides a rewarding resource for structural practice of grammar, but also a proper basis for review. In the selection of poem, firstly the teacher should consider the grammatical structure to be presented, practiced, or reviewed, then the level and the age of the students, next the theme and the length of the poem and its appropriateness to the objectives of class. It is advisable to select a poem from the 20th century poets, as older poems often provide a more difficult lexicon and syntax, and reflect some old-fashioned ideas. ${ }^{7}$ Several poems of W.H. Andrew, Robert Frost, Stanly Kunitz are suggested for the language teachers who want to use poems in their grammar lessons. In the teaching grammar, poems can be taught by using techniques as the song can. Here is the example of poem that can be used to teach grammar:

Fire and ice

By: Robert Frost

Some say the world will end in fire,

Some say in ice,

From what I've trusted of desire

I hold with those who favor fire

But if I have to perish twice

I think I know enough of hate

To say that for destruction ice

Is also great

And would suffice

7 Saricoban, Arif \& Essen Metin, Songs, Verse, and Games for Teaching Grammar, The Internet TESL, Journal, Vol. VI No. 10, October 2000. 
Since every class is different, teachers should creatively determine the teaching procedure. It is not advisable to apply one procedure too strictly. A teacher should adopt the activities according to the needs of the learners. However, it might not be very useful to use poems for young or for beginners.

d. Pictures and Maps

Maps and pictures can be used as practical and simple visual aids in the classrooms, especially to illustrate certain grammatical structure. Maps can stimulate learners' usage of:

1) Prepositional phrases (up the street, on the left, over the hills, etc.)

2) Question formulation (where, how, do I get there, can you tell me where is ... etc.)

3) Imperative (go ..., walk, look out for, ... etc.)

Here is the example of map that can be used to teach grammar:

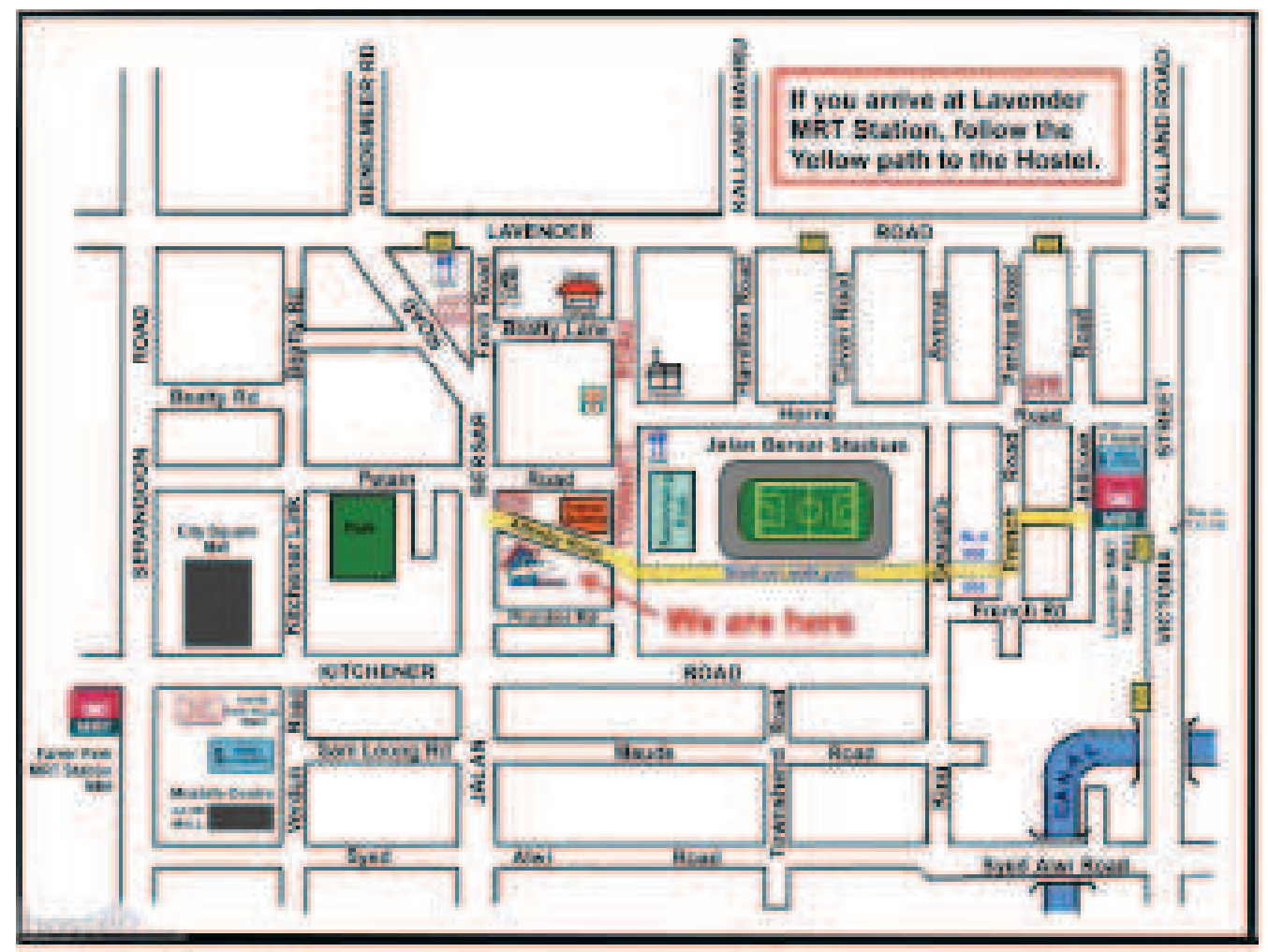

Pictures are also interesting and simple materials to teach grammar. They can be in the form of persons, object, or activities. Pictures can be used to practice in stating the location.

Teaching procedure using maps and picture can be done by asking the students to work in pairs. For example:

A: Where is the gas station?

$B:$ It is on Pine Street.

Teaching grammar using the forum techniques above has some advantages and disadvantages. The advantage is clearly explained. It is more apparent that teaching grammar can be supported 
by using such sources. Since the teaching is a developing art, which requires innovative and creative ideas to enrich its effectiveness, we must not hesitate to use such resources in classroom. They can assist our teaching grammar while providing a relaxed atmosphere and motivated students. Such activity is student-centered, hence, we give a chance to the students to express themselves during learning, and use the reserve of their minds. Thus, let our students use their long-term memory and learn effectively during such activities. On the test result it has the disadvantage. It is possible that some students will get low score because of their little attention on the form sentence during the teaching process but on the meaning of messages.

\section{Teaching Grammar Using Explanation}

In this technique the teachers are focusing on the form. In some situation it may be essential to go to the textbook and to go along with the students' effort to relate "textbook rules" with the example. The teachers tell the students about the explicit grammatical rules. Sometimes, depending on the level of difficulty of particular grammatical constructions, students may be asked to open the book to a certain page. At that time the teachers go through the rules. The example of explanation given by the teachers can be seen below:

Teacher:

In using simple present, we add the ending -s or -es to verb if the subject is first person singular, that is, when it refers to he, she, and it. For example: "My father works at the IBM company", and "Water boils at $100 \mathrm{C}$ degrees" (show on the board). In other cases, you can see here (point the other example) in "I usually get up at 5 every morning" and "They go to school by bus", we just have the infinitive of the verb or the way it is in the dictionary without 'to'. You can use Present Simple Tense to describe what you and others usually/often/sometimes do. For example, "My wife name is Linda. She works at the Giant. She is a cashier, and so on. Or we can use this tense to talk about facts that represent a universal truth. For example. "The sun rises in the east; Water boils at 100 C degrees. (Azar, 1989:86)

Sysoyev states that in this grammar explanation the teacher tries to make the routine activity, and that is why the teacher makes the example on the textbook. ${ }^{9}$ Even though, it sounds simple, this technique has a great effect on learners. It serves a bridge between what students consider 'theory', what is usually given in the textbook, on the other hand, and 'practical use', what students have discovered. In the explanation, it is important to make a connection between the examples and the explicit rules. This connection will help learners build on what they have already discovered. After the explanation of explicit rules, the students are supposed to do several practices from the textbook or those given by the teachers to know whether they really understand or not. The teaching process using explanation is not as interesting as the one using communicative technique because of the students' attention on the form no meaning.

8 Azar, Betty Schrampfer, 1989, Undestanding and Using English Grammar, New Jersey: Prantice Hall Regents.

9 Sysoyev, Pavel V, Integrative L2 Grammar Teaching: Exploration, Explanation, and Expression, The Internet TESL, Journal Vol. V, No. 6, June 1999. 


\section{Conclusion}

From the explanation above, it can be concluded that there are some ways of teaching grammar. Teacher can use communicative techniques (meaning-based) or explanation one (form-based) in presenting games, songs, poems, maps or pictures. Each has their own strength and weakness. Compared with teaching grammar using explanation, teaching grammar with communicative technique will make the teaching process interesting and the students will not get bored. In Indonesia CLT is a modified version to adopt teaching English skills such as reading, writing and and speaking. Structural approach is still applied for teaching language elements such as structure/grammar and vocabulary. Explanation method is used to develop reading skill. However, based on the data of test result by the students, the result of explanation technique is more effectively targeted better than CLT.[]

\section{Bibliography}

Azar, Betty Schrampfer, 1989, Undestanding and Using English Grammar, New Jersey: Prantice Hall Regents.

Fauziati, Endang, 2009, Introduction to Methods and Approaches in Second or Foreign Language Teaching, Surakarta: Pustaka Utama.

Howatt, A.R.R, 1985, A History of English Language Teaching, New York: Oxford U.P.

Perrine, Laurence, 1984, Literature: Structure, Sounds, and Sense, Tokyo: Harcourt Brance College Publishers.

Richars, Jack, C. et al, 1990, Interchange 1: English for International Communication, Australia: Cambridge University Press.

---------, 1991. Interchange 1: English for International Communication, Australia: Cambridge University Press.

Richards and Rodger, 1986, Approaches and Methods in Language Teaching, Cambridge: Cambridge University Press

Saricoban, Arif \& Essen Metin, Songs, Verse, and Games for Teaching Grammar, The Internet TESL, Journal, Vol. VI No. 10, October 2000.

Sysoyev, Pavel V, Integrative L2 Grammar Teaching: Exploration, Explanation, and Expression, The Internet TESL, Journal Vol. V, No. 6, June 1999. 